\title{
Work-Related Fatigue Factors among Hospital Nurses: An Integrative Literature Review
}

\author{
Bader Abdullah Alahmadi ${ }^{1}$, Manal Fehade Alharbi ${ }^{2}$ \\ ${ }^{I}$ Nursing Supervisor, The University of Sydney, Sydney-Australia; King Fahad Hospital, \\ Madinah-Saudi Arabia \\ ${ }^{2}$ Assistant Professor, Department of Maternity and Child Health Nursing, College of Nursing- \\ King Saud University, Riyadh-Saudi Arabia \\ Corresponding Author: Manal Fehade Alharbi (maalwahbi@ksu.edu.sa)
}

\begin{abstract}
Background: Due to the demanding nature of nurses' work and the current shortage of nurses, hospital nurses often find themselves working extra shifts, extended hours, and taking on more responsibilities. However, this added pressure on the body and mind results in fatigue which adversely affects nurses' health status as well as their ability to provide optimal health care procedures. Preventing fatigue and reducing its adverse consequences require comprehensive awareness about its diverse contributing factors.

Purpose: This study aimed to examine factors which influence fatigue among nurses employed in a hospital setting.

Methods: An integrative review was conducted to assess the quality of the research evidence, to find minor and major gaps in current research and the main issues in the area of the research and finally to bridge the research gaps. This integrative review identified a total of 12 relevant research studies from Cumulative Index to Nursing and Allied Health Literature (CINAHL), Medline, Embase, PsycINFO, and a manual search. Data were reviewed in May 2017, using an integrative review, and then interpreted, analyzed and synthesized to identify the key contributing factors that influence fatigue among hospital nurses.

Results: The review revealed that significant factors such as organizational factors, nursing work characteristics, psychosocial factors as well as individual characteristics and demand, influenced the nurse fatigue. Work shifts, specifically night shifts and extended work shifts without sufficient inter-shift recovery were linked to higher levels of fatigue. Conclusion: This review identified the significant factors affecting fatigue among nurses in hospital settings in various countries all around the world. Findings from this study may help healthcare organizations and policymaker to introduce strategies that mitigate fatigue among nurses.
\end{abstract}

Keywords: Fatigue; hospital; integrative review; nurses; work-related factors

\section{BACKGROUND}

Hospital nurses who provide patient care service often experience temporal demand and heavier workload due to the shortage of staff and potential overtime. Nurses encounter nonstandard work schedules, long works hours and circadian adjustment to night shift which is physically, mentally and emotionally strenuous (Steege \& Rainbow, 2017). Thus, work-related fatigue has become a significant risk for nurses working in hospitals 
and has consequently led to poor outcomes such as reduced mental acuity, degradation in performance and errors (Canadian Centre for Occupational Health and Safety, 2017).

In hospitals, it is common for nurses to work extremely long shifts. The Australian Bureau of Statistics reported in 2010 that $75 \%$ of shift workers were health professionals. This high proportion of shift workers among nurses was also prevalent in the United States, where nurses account for roughly $60 \%$ of shift-work schedules (Bureau of Labor Statistics, 2015). According to the Canadian Centre for Occupational Health and Safety (2017), shift work can cover different work patterns, which include shift rotation or changes to a set schedule. Night shift work, day shift work, 12-hour, and rotational shifts are known to be associated with work-related fatigue for hospital nurses (Han, Trinkoff, \& Geiger-Brown, 2014; Smith-Miller, Shaw-Kokot, Curro, \& Jones, 2014).

Not surprisingly, the highest level of fatigue occurs among night-shift nurses (Winwood, Winefield, \& Lushington, 2006). Some studies investigated the phenomena of fatigue among hospital nurses such as Palhares, Corrente, and Matsubara (2014) who confirm that the physiological impact of poor sleep quality and disturbances on nurses' circadian rhythms can lead to fatigue among hospital staffs. MacKusick and Minick (2010) reported that psychosocial factors were a part of the reasons why nurses leave their profession. Barton (1994) and Smith-Miller et al. (2014) examined a nurse's decision to work at night while Han et al. (2014) studied work and non-work factors on acute fatigue and chronic fatigue. Another study by Lockley, Barger, Ayas, Rothschild, Czeisler, and Landrigan (2007) assessed the effects of work schedules on sleep and performance. Several psychosocial factors play a role in fatigue among nurses. A better understanding of these contributing factors enables a broader view of previous studies related to fatigue. Thus, the generalizability of their outcomes to hospital nurses should be considered with caution.

\section{PURPOSE}

This integrative review sought a broader view of studying fatigue and explored the factors influencing work-related fatigue among hospital nurses.

\section{METHODS}

An integrative systematic literature review was the chosen methodology of this study which consisted of five main stages. The first was formulating a research question, and the second was conducting a systematic literature search using the terms specified in the formulated research question. The third was collecting data and literature needed to be evaluated. The fourth stage was to analyze the findings, and the final stage was to interpret and transparently present these findings. The advantages of an integrative literature review design are its ability to assess the quality of the research evidence, to find minor and significant gaps in current research, identifying the main issues and research gaps to be bridged (Whittemore \& Knafl, 2005).

\section{Search method}

The search was performed in May 2017 using four electronic databases (e.g., Cumulative Index to Nursing and Allied Health Literature (CINAHL), Medline, Embase, and PsycINFO), and a manual search. Three keywords were used (i.e., fatigue, nurses, and 
hospital) and joined by the logical operators AND and OR (e.g., nurse OR nurses AND fatigue OR lack of energy AND hospital OR hospitals). The inclusion criteria for the three components were established, including the fatigue component which covers three types of fatigue including physical, mental, and emotional fatigue; nurses which cover nursing staff who work in hospitals for at least 24 hours a week; and finally, the hospital which covers all care units and departments in the hospitals, for instance, the medical-surgical unit, intensive care unit, and the emergency department. The exclusion criteria were: (1) the studies with trials in non-hospital settings, (2) studies that involved healthcare providers other than hospital nurses, (3) studies related to religious fasting, and (4) studies related to patients' healthcare outcomes.

\section{Search outcomes}

As shown in Figure 1, the literature search of the databases retrieved 1137 articles from Medline ( $n=443)$, CINAHL ( $n=363)$, Embase (242) and PsycINFO (89). One article was retrieved via manual search. Due to duplication, 751 articles were excluded, leaving 387 articles. Records were screened using the title and abstracts, and 308 were excluded under exclusion criteria 1, 2 and 3. Twenty-seven studies were assessed using full-text screening, and 67 articles were excluded under exclusion criterion 4 . The 12 remaining papers were critically appraised.

\section{Quality appraisal}

The inclusion of high-quality papers will enhance the quality of the integrative review. It has been argued that an assessment of the quality of the included studies has no standard because any evaluation of the quality of research is complicated (Whittemore \& Knafl, 2005). Nevertheless, the quality appraisal of the studies included in this literature review was performed. Different quality appraisal tools were used for different study designs. The Critical Appraisal Skills Programme (CASP) checklist was used to assess the quality of the included studies (cohort and cross-sectional). The CASP checklist consists of 12 questions which are based on the validity of the outcomes (questions 1-6), the outcome of the study (questions 7-9), and the internal significance of the outcomes (questions 1012). Also, the CASP checklist for qualitative studies was used to assess the quality of one included study. It consists of 10 questions that cover the validity of the results, their significance, and their impact locally (Critical Appraisal Skills Programme, 2018). The qualitative study by Steege \& Rainbow (2017) used in this integrative literature review was essential in addressing the issue of fatigue in relation to other health system factors or challenges. The overall quality of the included studies was good, as they had significant and strong outcomes. Tables 1 and 2 show the outcomes of the quality appraisal of the included studies using different appraisal tools for different study designs.

\section{Data extraction}

Data extraction was measured by the overall ability to identify the principal contributing factors that influence fatigue among hospital nurses. The methodology, participants and reported themes used to examine and assess the correlation between varying factors and fatigue among nurses in Steege and Rainbow's (2017) qualitative study are presented in Table 3. Nurse fatigue and underlying characteristics such as the country in which the study was conducted, study aim, research design, sample size, sample characteristics, the method of analysis, tools used and key results are summarized for all 11 quantitative 
research studies in Table 3. A matrix illustrating the data gathered and collected was also compiled to enhance the visualization of data is presented in Table 4.
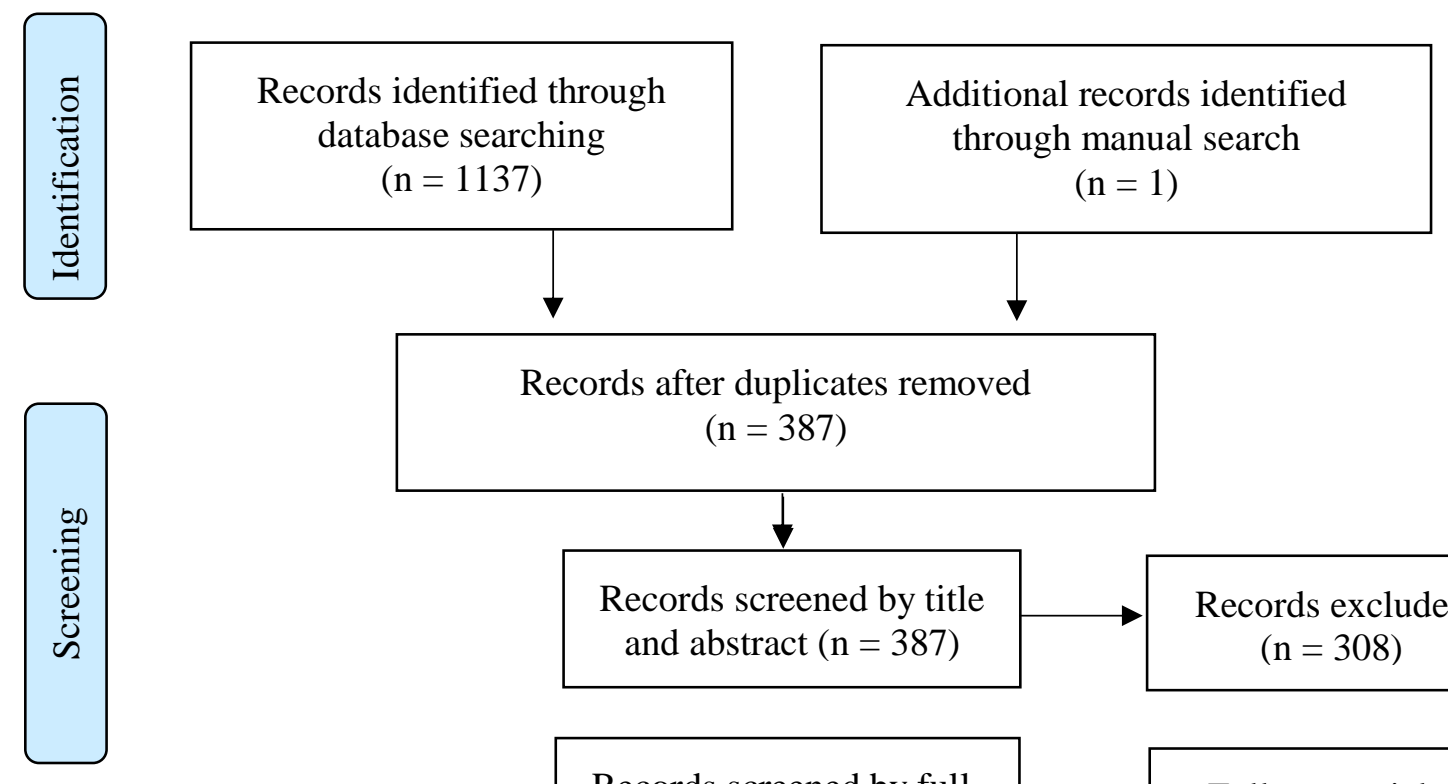

Records after duplicates removed $(\mathrm{n}=387)$
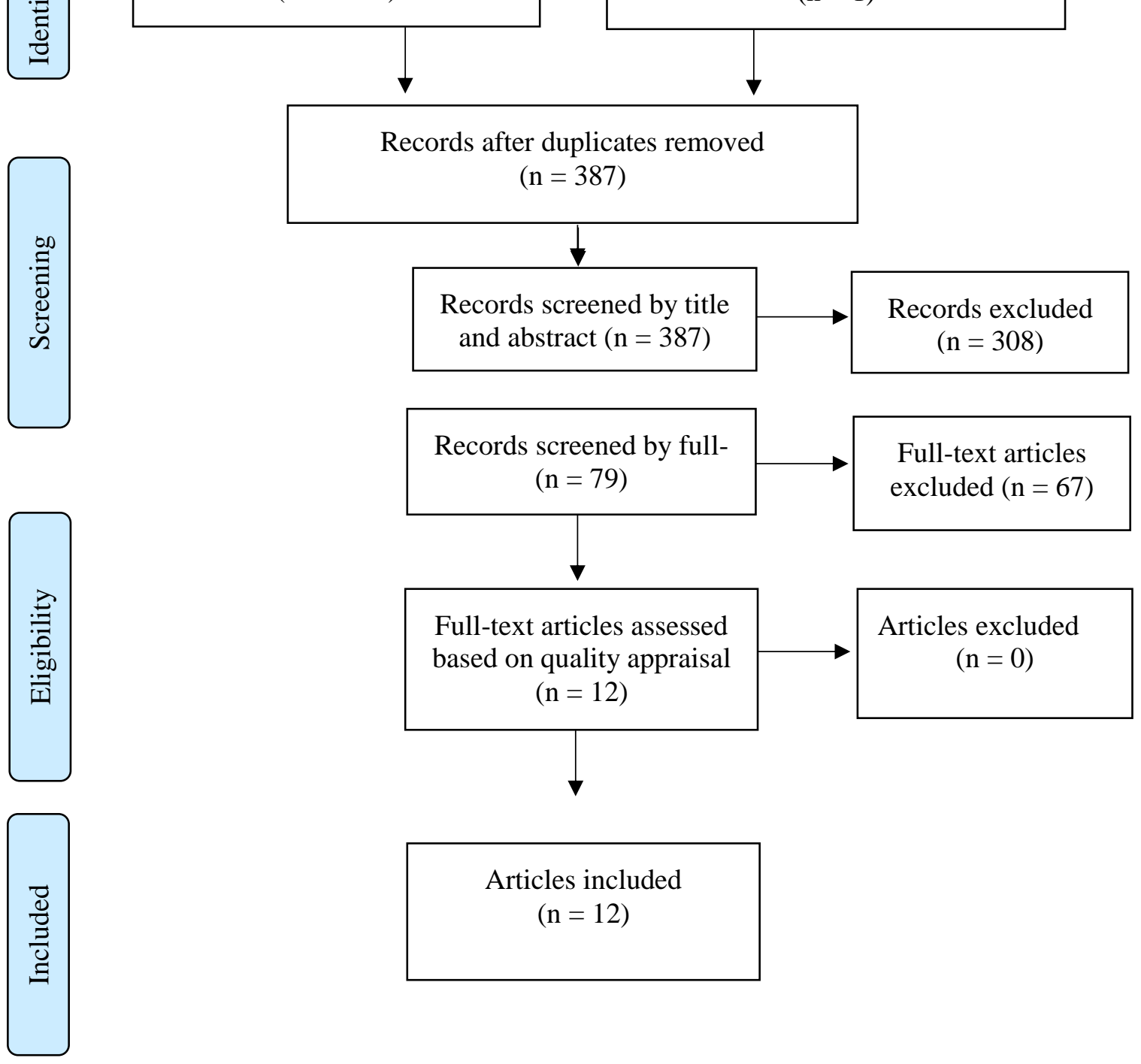

Articles included $(\mathrm{n}=12)$

Figure 1. PRISMA flow chart for the article selection

\section{RESULTS}

Of the 12 studies examined, five were conducted in hospitals located throughout the United States (Chen, Davis, Daraiseh, Pan, \& Davis, 2014; Han et al., 2014). The studies in the USA were conducted in Southern California (Kunert, King, \& Kolkhorst, 2007), the Midwest (Steege \& Rainbow, 2017), and Texas (Morelock, 2016). Five studies were conducted in Eastern Asia, specifically in hospitals in Brunei Darussalam (Rahman, Abdul-Mumin, \& Naing, 2016), Chenghu City in China (Fang, Kunaviktikul, Olson, Chowtawan, \& Kaewthummanukul, 2008), Ishikawa in Japan (Nagai et al., 2011), South Korea (Jung \& Lee, 2015), and Taiwan (Yuan et al., 2011). The studies by Eldevik, Flo, 
Moen, Pallesen, and Bjorvatn (2013) and Winwood et al. (2006) were performed in Norway and South Australia, respectively. Five studies employed a cross-sectional research design; however, the nature of the design varied as two of the quantitative studies used only a cross-sectional design (Han et al., 2014; Rahman et al., 2016). The other three quantitative cross-sectional studies were descriptive in nature, of which one utilized a descriptive cross-sectional research design (Chen et al., 2014), one had a descriptive cross-sectional, correlational study design (Fang et al., 2008) and one used a descriptive cross-sectional, exploratory, correlational research design (Jung \& Lee, 2015). Two quantitative research studies, Eldevik et al. (2013) and Winwood et al. (2006), used questionnaires. An exploratory research design was inherent to two studies, one qualitative study (Steege \& Rainbow, 2017) and one quantitative study (Morelock, 2016). Kunert et al. (2007) used a descriptive research design, while Nagai et al. (2011) used a longitudinal study design, and Yuan et al. (2011) utilized observational research. The only qualitative study (Steege \& Rainbow, 2017) used semi-structured interviews to assess the consequences of nursing fatigue. Tools used are listed in Table 3.

Mental demands, physical demands, and workload influence fatigue among hospital nurses. Nurses who had more psychological demands at work and more quantitative work demands due to workload experienced high levels of acute fatigue, as shown in Table 3 (Han et al., 2014). A similar relational trend was observed between work demands and chronic fatigue. Psychological demands and quantitative work demands were correlated with chronic fatigue, as represented by $t=2.10, p=0.04$ and $t=2.23, p=0.03$, respectively (Han et al., 2014). Intensive care unit nurses often have a high level of physical and mental demands. According to Fang et al. (2008), intensive care unit nurses experience more acute and chronic fatigue compare to their colleagues in other general wards. Furthermore, working conditions and related factors explained an additional $0.2 \%$ of the variance relative to nurse fatigue (Jung \& Lee, 2015).

An overview of all psychosocial factors, including job dissatisfaction, job stress, meaningfulness of work, and social support is provided. A significant correlation was established between various psychosocial factors and fatigue. Rahman et al. (2016) found a low to moderate association between psychological stressors related to work and fatigue. Using simple linear regression, a statistically significant relationship was shown across a total of 17 psychosocial variables (bullying, burnout, commitment to workplace, emotional demands, job satisfaction, justice and respect, meaning of work, physical violence, quality of leadership, reward, self-rated health, stress, superior social support, threats of violence, trust in management, and work-family conflict) and acute as well as chronic fatigue. Of these 17 psychosocial factors, a multiple linear regression showed that decision latitude, job stress, self-rated health, trust in management, and work-family conflict were the most significant variables that demonstrated a linear relationship with chronic fatigue at a significance level of $p=0008, p<0.001, p=0.011, p=0.001$ and $p=0.013$, respectively; however, only four significant variables, including burnout $(p<0.001)$, commitment to the workplace $(p=0.010)$, self-rated health $(p=0.001)$, and trust in management $(p=0.021)$ were associated with acute fatigue (Rahman et al., 2016). Job dissatisfaction, a negative attitude toward one's job, is common among hospital nurses. Lower levels of job satisfaction are associated with high levels of acute fatigue 
and chronic fatigue (Han et al., 2014). Moreover, Fang et al.'s (2008) study showed that decreased job satisfaction is linked to increased chronic fatigue.

Job stress is characterized by the demands associated with a nurse's current role and responsibilities. Increased job stress occurs when hospital nurses are not supported by colleagues and supervisors, which impacts the meaningfulness of work and social support (Han et al., 2014; Jung \& Lee, 2015). Meaningfulness at work is based on the significance a hospital nurse attributes to their perceptions of work (Han et al., 2014). Social support, a key factor known to influence nurse fatigue directly, is based on a nurse's interaction with colleagues and management (Jung \& Lee, 2015). Social support by colleagues and management impacts a nurse's perceived level of comfort. The findings of this integrative review revealed that hospital nurses are exposed to various psychosocial factors, which define their mental, emotional, and physical status. Of all the factors identified, five psychosocial variables, including decision latitude, job stress, self-rated health, trust in management, and work-family conflict were significantly linked to chronic fatigue. Results also found that decreased levels of job satisfaction were linked to high levels of acute and chronic fatigue. Additional findings revealed that job stress and social support were positively associated with fatigue. Hospital nurses strive to be part of a team; however, less social support from colleagues and supervisors is correlated with more acute and chronic fatigue. Similar findings were noted as lower meaningfulness at work influenced more significant levels of chronic fatigue.

However, conflicting results were found by Winwood et al. (2006), who identified a significantly lower pattern of maladaptive fatigue among hospital nurses with partners and dependents (children). Additional findings (as reported in Table 3) show a relatively higher mean fatigue score among non-partnered hospital nurses with no dependents irrespective of shift compared to partnered hospital nurses with dependents (Winwood et al., 2006). Dependents are not deemed a key indicator of chronic fatigue scores among hospital nurses with partners. Additional findings demonstrate that the mean fatigue score of unpartnered hospital nurses with dependents is worse compared to unpartnered hospital nurses without dependents, as well as partnered hospital nurses both with and without dependents (Winwood et al., 2006). Such condition is reflective of the difficulties usually encountered by hospital nurses who are responsible for supporting families without assistance.

\section{DISCUSSION}

Generally, the findings indicate significant associations between various factors, including organizational, nursing work characteristics, psychosocial factors, individual characteristics, demand, and fatigue among nurses. The scheduling of shifts is an issue of great importance in determining productivity and alertness at work. Nursing work is highly taxing to the body and necessitates adequate rest, hence calling for the proper development of work schedules (Stimpfel, Sloane, \& Aiken, 2012). In this regard, one of the factors that have been observed to have detrimental effects on the fatigue status of nurses is inter-shift recovery (Eldevik, 2013; Fang et al., 2008; Winwood et al., 2006). The shortening of such a period means reduced rest time. According to Yuan et al. (2011), acute fatigue due to low inter-shift recovery is linked to chronic fatigue. To understand the impact of chronic fatigue, it is essential to learn the circadian rhythms, influenced by 
external and internal factors (Niu, Chung, Chen, Hegney, O'Brien, \& Chou, 2011). Human beings are considered to be diurnal, which means that their "clocks" are similar to those of the 24-hour system that results from the spinning of the earth on its axis, causing day and night (Niu et al., 2011). Most behavioral, physiological, and biological processes, including the sleep-wake cycle, mood, and adrenaline release, consist of the interaction of cyclical circadian rhythms. The natural release of adrenaline, timedependent corticosteroids, and sleep-dependent hormones is dependent on time (Niu et al., 2011). As such, the body releases high levels of adrenaline and corticosteroids during the day with a drop-in level occurring at night. Sleep-dependent hormones are increasingly secreted during the night (Morris, Aeschbach, \& Scheer, 2012). Such biological rhythms are affected by any shift work that interrupts an individual's sleep time. This concept is an important consideration to define the impact of reduced intershift recovery time on sleep patterns and levels of fatigue. The findings of this study demonstrate such patterns, as multiple studies indicate that there is a distinct relationship between and among reduced time, nurses' shifts and fatigue (Eldevik et al., 2013; Fang et al., 2008; Winwood et al., 2006). The cyclical circadian rhythms, as noted earlier, are noteworthy in a review of shift-work patterns. It is clear that the therapeutic value of the sleep and recovery times of night nurses is reduced, given that they are expected to rest when the release of adrenaline is highest.

Conversely, reduced levels of adrenaline and corticosteroids during night shifts may result in reduced efficiency of nurses working such shifts due to increased fatigue (Boivin $\&$ Boudreau, 2014). Such association is echoed by the findings of Kunert et al. (2007) and Fang et al. (2008), which indicated increased levels of fatigue among evening and night nurses as compared to nurses who work during the day. The low levels of sleepdependent hormones and the high levels of adrenaline and corticosteroids released during the day could explain the poor quality of sleep, reduced sleep efficiency and duration, and sleep latency among night nurses, as established by the findings of Kunert et al. (2007) and Morelock (2016).

Nurses are experiencing an increase in workload in the healthcare environment. This could be attributed to four main factors: an increase in demand for nurses, insufficient individuals entering the nursing profession, increased over time and decreased staffing, and a reduction in the length of stay among patients (Bae, Brewer, \& Kovner, 2012). These factors are interconnected in a causative fashion, forming a cycle of events. To start with, the increase in demand for nurses may correspond to the increase in the aging population, as this population experiences increased demand for healthcare services. This increase in demand is, however, not met, as the supply of nurses remains inadequate. Such a shortage in the supply of nurses results in an increased workload for the nurses who are available (Stimpfel et al., 2012). Increases in the cost of health care have also led most healthcare institutions to reduce their staffing in order to increase their profit margins. Also, mandatory overtime policies have been put in place to compel nurses to work more, which has compounded an increase in nurses' physical and mental demands with an increase in workload. Most healthcare organizations also decreased the length of stay for patients due to the cost pressure, which has led to the admission of sicker patients and hence increased mental and physical demand to manage these patients (Bae et al., 2012). As a consequence of such demands, there is an increase in fatigue levels among nurses. 
As established by Fang et al. (2008), Han et al. (2014), and Jung and Lee (2015), nursing job demands are positively correlated with both acute fatigue and chronic fatigue. This fatigue could be attributed to the reduced rest that nurses have as a result of the increased demands in the workplace. The hospital work environment presents various job stressors and increased caregiving demands, including rapid cycles for admission and discharge and increased levels of patient acuteness, which call for employment of high levels of complex occupational skills by nurses. Smith-Miller et al. (2014) mentioned that the mental, emotional, and physical demands associated with nursing work leads to burnout and sleepiness, which are indicative of fatigue. In this case, burnout is characterized by emotional depletion, depersonalization, and a developed sense of disconnectedness. The findings by Fang et al. (2008) indicate more fatigue among nurses who work in the intensive care unit than those in the other wards, which could explain the different levels of burnout in the two settings. The level of mental demand experienced by nurses working in the intensive care unit is high, as they are faced with critical decisions about the patients; hence their development of burnout, especially when they are overwhelmed by the mental and physical demands, and cases where they are confronted by adverse outcomes of care, such as the death of a patient. Numerous studies have examined the trauma and tragedy that patients and their families experience in the wake of illness and death, however, there has been limited research carried out to determine how nurses respond to continuous exposure to cases of premature death and profound loss. In his study of "compassion fatigue," Boyle (2011) established that nurses are also affected by the various traumatic events that they face in their daily activities. These events have a detrimental effect on their psychological well-being, which may result in burnout and related stress, especially in cases where they had developed an emotional attachment to patients under their care. As reported by Rahman et al. (2016), stress and burnout are positively correlated with fatigue among nurses. When nurses develop depersonalization and emotional exhaustion due to continuous exposure to traumatic events, they report increased fatigue that can be deleterious to the delivery of their services.

Factors influencing satisfaction with work are also a primary determinant of burnout and resultant fatigue. In most cases, as a result of reduced staffing and increased demand for healthcare, nurses are forced to work extra hours, with limited breaks and heavy workload, as the ratio of patients to nurses is high (Cimiotti, Aiken, Sloane, \& Wu, 2012). Such factors contribute to an increased level of dissatisfaction among nurses, which leads to burnout, characterized by disconnectedness with the work and reduced commitment. Fang et al. (2008) and Steege and Rainbow (2017) reported a connection between nurse dissatisfaction and fatigue. Such dissatisfaction results from the increased demands and expectations about the role of nurses in practice and the related implications regarding their physical and mental wellbeing. Apart from their roles in providing health care, some nurses also have families that they are responsible for in different ways. As such, they are faced with challenges balancing the demands of their work and those of their homes (Chen et al., 2014).

In most cases, due to the various roles that they play at home, nurses fail to have enough sleep and rest, even when away from duty, which results in increased fatigue. This echoes the findings of Rahman et al. (2016), which established a correlation between chronic fatigue and work-family conflict. Moreover, concerning the need for self-actualization, 
as defined by Maslow, nurses desire to be appreciated regarding their contribution to the healthcare process (Lester, 2013). Such appreciation allows for the development of a sense of belonging and a feeling of achievement, which facilitates increased commitment to the work. On the other hand, lack of appreciation for the contribution of nurses results in stress and burnout due to depersonalization, ultimately leading to increased rates of fatigue, while the nurses involved find their jobs increasingly burdensome. The findings of this review support such a relationship, as Han et al. (2014) demonstrated an association between lack of social support from both nurse supervisors and their coworkers and the development of acute fatigue. The demographic factors of different nurses, including age, gender, and experience, also contribute to the development of fatigue. Like other professions, nurses are more likely to obtain supervisory and managerial positions as they age, mostly owing to their experience and familiarity with the management of various nursing situations. Most of the responsibilities adopted in management are carried out during the day shift, reducing the chances of fatigue from working night shifts. Also, the roles adopted in supervision and management are less taxing, and hence less likely to lead to fatigue as with young and newly-employed nurses who hold junior positions within an organization. This is consistent with the findings of Winwood et al. (2006) and Rahman et al. (2016), who established that older nurses were less likely to develop fatigue than their junior counterparts as they worked in senior positions that entailed less physical work and fewer or no night shifts.

Nevertheless, older nurses who do not hold senior positions are likely to develop more fatigue than their younger counterparts due to physiological deterioration as they age. This is in line with the findings of Chen et al. (2014) and Kunert et al. (2007), who established that older nurses were more likely to experience acute fatigue compared to younger nurses. As mentioned earlier, nurses who have families also face different levels of responsibilities away from work, which may interfere with their ability to get enough rest (Chen et al., 2014). However, in the case where such nurses have partners, they are likely to experience less fatigue, as they receive both social and physical support from their partners, especially with regards to caring for dependents. This is demonstrated in the findings of Winwood et al. (2006), whereby they established that nurses with spouses receive the social support required to reduce fatigue.

The inclusiveness of the utilized research studies, as well as the recruitment of nurse participants from various hospital units all around the world (Australia, Eastern Asia, Europe, and the USA), serves as a strength of this study. The inclusion of these studies increases the sample representation, which increases the generalizability of research findings and provides a global view of the phenomena of interest. This study does however also have some limitations, including a lack of consensus in the definition of fatigue across the studies reviewed; the studies were also filtered by language, allowing only for those that were published in English. Also, most of the studies, including those by Chen et al. (2014), Eldevik et al. (2013), Fang et al. (2008), Han et al. (2014), and Nagai et al. (2011), involve female participants, which leaves the question of the relevance of the reported findings for male nurses, and impedes cross-gender generalizability of the conclusions that can be drawn. This integrative review is also limited by the fact that the majority of the research studies employ a cross-sectional design that identifies causal relationships between work and non-work factors related to 
fatigue and recovery. Another significant limitation lies in the reported nature of the tools used to examine and assess levels of nurse fatigue (Winwood et al., 2006). This study provides an understanding of the factors that determine fatigue among nurses employed in a hospital setting, identifying the association between a number of night shifts and extended work shifts and acute and chronic fatigue. The Joint Commission (2011) has increased the focus on nurse fatigue and prolonged work shifts. This will enhance organizational awareness, thus enabling hospitals to develop policies and standards to increase the presence of social support in the workplace while reducing the possibility of nurse fatigue (e.g., developing health-promoting scheduling to ensures sufficient recovery time and providing support at work). Also, educational programs for nurses may be used, teaching them the best way of enhancing inter-shift recovery. Moreover, providing choices on scheduling pattern (e.g., length of shifts, number of shifts and starting time) would be a solution for better recovery (Grade et al., 2012). Due to the association between acute fatigue and chronic fatigue, organizations must focus on identifying and mitigating the possibility of acute fatigue.

\section{CONCLUSION}

This integrative review found that an amalgamation of factors, including organizational factors, nursing work characteristics, psychosocial factors, individual characteristics, and demand, influence fatigue among nurses in a hospital setting. As such, poor scheduling resulting in nurses working overtime and having fewer breaks is associated with increased levels of fatigue. On the other hand, night shifts were also established as contributing to increased fatigue, as they disrupt the circadian cycle and interfere with sleep. Psychological and social factors, such as stress and social support in the workplace, were also linked to fatigue. Demographic factors, such as age, marital status, and nursing experience, were also associated with fatigue. It is clear that nurse fatigue is a problem that could jeopardize the health of both the nurses and the patients. The findings of this integrative review may help policymakers to develop strategies that contribute to mitigating fatigue among hospital nurses.

\section{ACKNOWLEDGMENTS:}

The authors are thankful to Dr. Sandra West from The University of Sydney for the tremendous support and guide during this research.

\section{Funding Statement}

The author received no financial support for this research, authorship, and/or publication of this study.

\section{Conflict of Interest statement}

There was no conflict of interest, financial or other, exists. Each author has participated and contributed sufficiently to take public responsibility for appropriate portions of the content. 


\section{REFERENCES}

Australian Bureau of Statistics. (2010). Australian labour market statistics (No. 6105.0). Retrieved from http://www.ausstats.abs.gov.au/ausstats/subscriber.nsf/0/ B9BE5F9EA40AA538CA2577B50 00CB666/\$File/61050_oct\%202010.pdf

Bae, S. H., Brewer, C. S., \& Kovner, C. T. (2012). State mandatory overtime regulations and newly licensed nurses' mandatory and voluntary overtime and total work hours. Nursing Outlook, 60(2), 60-71. doi: 10.1016/j.outlook.2011.06.006

Barton, J. (1994). Choosing to work at night: A moderating influence on individual tolerance to shift work. Journal of Applied Psychology, 79(3), 449-454.

Boivin, D. B., \& Boudreau, P. (2014). Impacts of shift work on sleep and circadian rhythms. Pathologie Biologie, 62(5), 292-301.

Boyle, D. (2011). Countering compassion fatigue: A requisite nursing agenda. The Online Journal of Issues in Nursing, 16(1):2

Bureau of Labor Statistics. (2015). Occupational Outlook Handbook, 2014-15 Edition, Registered Nurses. Retrieved from http://www.bls.gov/ooh/ healthcare/registerednurses.htm

Canadian Centre for Occupational Health and Safety. (2017). Rotational shift-work: OSH answers. Retrieved from http://www.ccohs.ca/oshanswers/ergonomics/ shiftwrk.html

Chen, J., Davis, K. G., Daraiseh, N. M., Pan, W., \& Davis, L. S. (2014). Fatigue and recovery in 12-hour dayshift hospital nurses. Journal of Nursing Management, 22(5), 593-603.

Cimiotti, J. P., Aiken, L. H., Sloane, D. M., \& Wu, E. S. (2012). Nurse staffing, burnout, and health care-associated infection. American Journal of Infection Control, 40(6), 486. doi: 10.1016/j.ajic.2012.02.029

Critical Appraisal Skills Programme (2018). CASP (Qualitative) Checklist. Retrieved from https://casp-uk.net/wp-content/uploads/2018/01/CASP-QualitativeChecklist-2018.pdf.

Eldevik, M. F., Flo, E., Moen, B. E., Pallesen, S., \& Bjorvatn, B. (2013). Insomnia, excessive sleepiness, excessive fatigue, anxiety, depression and shift work disorder in nurses having less than 11 hours in-between shifts. PLoS one, 8(8), e70882.

Fang, J., Kunaviktikul, W., Olson, K., Chontawan, R., \& Kaewthummanukul, T. (2008). Factors influencing fatigue in Chinese nurses. Nursing Health Sciences, 10(4), 291299.

Garde, A. H., Albertsen, K., Nabe-Nielsen, K., Carneiro, I. G., Skotte, J., Hansen, S. M., . . . Hansen, A. M. (2012). Implementation of self-rostering (the PRIO project): Effects on working hours, recovery, and health. Scandinavian Journal of Work, Environment \& Health, 38(4), 314-326.

Han, K., Trinkoff, A. M., \& Geiger-Brown, J. (2014). Factors associated with workrelated fatigue and recovery in hospital nurses working 12-hour shifts. Workplace Health Safety, 62(10), 409-414. doi:10.3928/21650799-20140826-01

Jung, H. S., \& Lee, B. (2015). Contributors to shift work tolerance in South Korean nurses working rotating shift. Applied Nursing Research, 28(2), 150-155.

Kunert, K., King, M. L., \& Kolkhorst, F. W. (2007). Fatigue and sleep quality in nurses. Journal of Psychosocial Nursing and Mental Health Services, 45(8), 30-37.

Lester, D. (2013). Measuring Maslow's hierarchy of needs. Psychological Reports, 113(1), 15-17. doi: 10.2466/02.20.PR0.113x16z1 
Lockley, S. W., Barger, L. K., Ayas, N. T., Rothschild, J. M., Czeisler, C. A., \& Landrigan, C. P. (2007). Effects of health care provider work hours and sleep deprivation on safety and performance. Joint Commission Journal on Quality and Patient Safety, 33(11), 7-17.

MacKusick, C. I., \& Minick, P. (2010). Why are nurses leaving? Findings from an initial qualitative study on nursing attrition. Medsurg Nursing: Official Journal of the Academy of Medical- Surgical Nurses, 19(6), 335-340.

Morelock, S. (2016). Sustained vigilance and errors in critical care. Nursing Critical Care, 11(6), 38-47.

Morris, C. J., Aeschbach, D., \& Scheer, F. A. J. L. (2012). Circadian system, sleep and endocrinology. Molecular and Cellular Endocrinology, 349(1), 91-104. doi: 10.1016/j.mce.2011.09.003

Nagai, M., Morikawa, Y., Kitaoka, K., Nakamura, K., Sakurai, M., Nishijo, M., . . . Nakagawa, H. (2011). Effects of fatigue on immune function in nurses performing shift work. Journal of Occupational Health, 53(5), 312-319. doi:10.1539/joh.100072-OA

Niu, S. F., Chung, M. H., Chen, C. H., Hegney, D., O’Brien, A., \& Chou, K. R. (2011). The effect of shift rotation on employee cortisol profile, sleep quality, fatigue, and attention level: A systematic review. Journal of Nursing Research, 19(1), 68-81.

Palhares, V. D., Corrente, J. E., \& Matsubara, B. B. (2014). Association between sleep quality and quality of life in nursing professionals working rotating shifts. Revista de Saude Publica, 48(4), 594-601.

Rahman, H. A., Abdul-Mumin, K., \& Naing, L. (2016). A study into psychosocial factors as predictors of work-related fatigue. British Journal of Nursing, 25(13), 757-763. doi:10.12968/bjon.2016.25.13.757

Smith-Miller, C. A., Shaw-Kokot, J., Curro, B., \& Jones, C. B. (2014). An integrative review: Fatigue among nurses in acute care settings. JONA: The Journal of Nursing Administration, 44(9), 487-494. doi:10.1097/NNA.0000000000000104

Steege, L. M., \& Rainbow, J. G. (2017). Fatigue in hospital nurses - 'Supernurse' culture is a barrier to addressing problems: A qualitative interview study. International Journal of Nursing Studies, 67, 20-28.

Stimpfel, A. W., Sloane, D. M., \& Aiken, L. H. (2012). The longer the shifts for hospital nurses, the higher the levels of burnout and patient dissatisfaction. Health Affairs, 31(11), 2501-2509. doi:10.1377/hlthaff.2011.1377

The Joint Commission. (2011). The Joint Commission Sentinel Events Alert. A complimentary publication of The Joint Commission, 48, 1-4.

Whittemore, R., \& Knafl, K. (2005). The integrative review: Updated methodology. Journal of Advanced Nursing, 52(5), 546-553.

Winwood, P. C., Winefield, A. H., \& Lushington, K. (2006). Work-related fatigue and recovery: The contribution of age, domestic responsibilities and shiftwork. Journal of Advanced Nursing, 56(4), 438-449. doi:10.1111/j.1365-2648.2006. 04011.x

Yuan, S. C., Chou, M. C., Chen, C. J., Lin, Y. J., Chen, M. C., Liu, H. H., \& Kuo, H. W. (2011). Influences of shift work on fatigue among nurses. Journal of Nursing Management, 19(3), 339-345. 
Appendix

Table 1. Outcomes of the quality appraisal of the cohort \& cross-sectional included studies

\begin{tabular}{|c|c|c|c|c|c|c|c|c|c|c|c|c|c|}
\hline \multicolumn{14}{|c|}{ Critical Appraisal Skills Programme (CASP) checklist for cohort studies } \\
\hline & \multicolumn{6}{|c|}{$\begin{array}{l}\text { Questions based on the validity of } \\
\text { the outcomes }\end{array}$} & \multicolumn{3}{|c|}{$\begin{array}{l}\text { Questions based } \\
\text { on outcome of } \\
\text { the study }\end{array}$} & \multicolumn{3}{|c|}{$\begin{array}{l}\text { Questions based } \\
\text { on the internal } \\
\text { significance of the outcomes }\end{array}$} & \multirow[t]{2}{*}{ Quality } \\
\hline Author/Year & Q1 & Q2 & Q3 & Q4 & $\begin{array}{l}\text { Q5 } \\
\text { A } \\
\text { B }\end{array}$ & $\begin{array}{l}\text { Q6 } \\
\text { A } \\
\text { B }\end{array}$ & Q7 & Q8 & Q9 & Q10 & Q11 & Q12 & \\
\hline Moreloc-k (2016) & $\sqrt{ }$ & $\sqrt{ }$ & - & - & - & $\begin{array}{l}- \\
-\end{array}$ & NA & NA & $\sqrt{ }$ & $\sqrt{ }$ & $\sqrt{ }$ & $\begin{array}{l}\text { Recommend } \\
\text { changes }\end{array}$ & Good \\
\hline Nagai et al. (2011) & $\sqrt{ }$ & $\sqrt{ }$ & $\sqrt{ }$ & $\sqrt{ }$ & $\begin{array}{l}\sqrt{ } \\
\sqrt{ }\end{array}$ & $\begin{array}{l}\sqrt{ } \\
\sqrt{ }\end{array}$ & NA & NA & $\sqrt{ }$ & $\sqrt{ }$ & $\sqrt{ }$ & Recommend & Good \\
\hline \multicolumn{14}{|c|}{ CASP checklist of a cross-sectional study (CEBM) } \\
\hline Eldevik et al. (2013) & $\sqrt{ }$ & $\sqrt{ }$ & - & $\sqrt{ }$ & $\sqrt{ }$ & - & $\sqrt{ }$ & $\sqrt{ }$ & $\sqrt{ }$ & $\sqrt{ }$ & $\sqrt{ }$ & $\sqrt{ }$ & Good \\
\hline Rahman et al. (2016) & $\sqrt{ }$ & $\sqrt{ }$ & - & $\sqrt{ }$ & - & $\sqrt{ }$ & $\sqrt{ }$ & $\sqrt{ }$ & $\sqrt{ }$ & $\sqrt{ }$ & $\sqrt{ }$ & $\sqrt{ }$ & Good \\
\hline Chen et al. (2014) & $\sqrt{ }$ & $\sqrt{ }$ & - & $\sqrt{ }$ & - & $\sqrt{ }$ & $\sqrt{ }$ & $\sqrt{ }$ & $\sqrt{ }$ & - & - & $\sqrt{ }$ & Good \\
\hline Han et al. (2014) & $\sqrt{ }$ & $\sqrt{ }$ & $\sqrt{ }$ & $\sqrt{ }$ & $\sqrt{ }$ & $\sqrt{ }$ & $\sqrt{ }$ & $\sqrt{ }$ & $\sqrt{ }$ & - & $\sqrt{ }$ & $\sqrt{ }$ & Good \\
\hline Fang et al. (2008) & $\sqrt{ }$ & $\sqrt{ }$ & - & $\sqrt{ }$ & $\sqrt{ }$ & $\sqrt{ }$ & $\sqrt{ }$ & $\sqrt{ }$ & $\sqrt{ }$ & $\sqrt{ }$ & - & $\sqrt{ }$ & Good \\
\hline Kunert et al. (2007) & $\sqrt{ }$ & - & - & $\sqrt{ }$ & $\sqrt{ }$ & $\sqrt{ }$ & $\sqrt{ }$ & $\sqrt{ }$ & $\sqrt{ }$ & - & $\sqrt{ }$ & $\sqrt{ }$ & Good \\
\hline Jung \& Lee (2015) & $\sqrt{ }$ & $\sqrt{ }$ & - & $\sqrt{ }$ & - & $\sqrt{ }$ & $\sqrt{ }$ & $\sqrt{ }$ & $\sqrt{ }$ & - & $\sqrt{ }$ & $\sqrt{ }$ & Good \\
\hline Winwood et al. (2006) & $\sqrt{ }$ & $\sqrt{ }$ & - & $\sqrt{ }$ & - & $\sqrt{ }$ & $\sqrt{ }$ & $\sqrt{ }$ & $\sqrt{ }$ & - & $\sqrt{ }$ & $\sqrt{ }$ & Good \\
\hline Yuan et al. (2011) & - & $\sqrt{ }$ & - & $\sqrt{ }$ & - & - & $\sqrt{ }$ & $\sqrt{ }$ & $\sqrt{ }$ & - & $\sqrt{ }$ & - & Neutral \\
\hline
\end{tabular}


Table 2. Outcomes of the quality appraisal of the CASP checklist for qualitative studies

\begin{tabular}{llllllllllll}
\hline Author/year & Q1 & Q2 & Q3 & Q4 & Q5 & Q6 & Q7 & Q8 & Q9 & Q10 & \\
$\begin{array}{l}\text { Steege \& Rainbow } \\
\text { (2017) }\end{array}$ & $\sqrt{ }$ & $\sqrt{ }$ & $\sqrt{ }$ & $\sqrt{ }$ & $\sqrt{ }$ & $\sqrt{ }$ & $\sqrt{ }$ & $\sqrt{ }$ & $\sqrt{ }$ & Considered & Good \\
\hline
\end{tabular}

Table 3. Characteristics of quantitative studies

\begin{tabular}{|c|c|c|c|c|c|c|}
\hline $\begin{array}{l}\text { Authors, Year, \& } \\
\text { Country }\end{array}$ & $\begin{array}{l}\text { Study } \\
\text { Aim }\end{array}$ & $\begin{array}{l}\text { Research } \\
\text { Design }\end{array}$ & $\begin{array}{l}\text { Sample Size and } \\
\text { Characteristics }\end{array}$ & $\begin{array}{l}\text { Method of } \\
\text { analysis }\end{array}$ & Tools used & $\begin{array}{l}\text { Results Related to Nurse } \\
\text { Fatigue }\end{array}$ \\
\hline $\begin{array}{l}\text { Chen et al. (2014) } \\
\text { United State }\end{array}$ & $\begin{array}{l}\text { To explore the status of } \\
\text { acute-chronic fatigue } \\
\& \text { inter-shift recovery } \\
\text { among12-hours shift } \\
\text { nurses }\end{array}$ & $\begin{array}{l}\text { Cross-sectional } \\
\text { survey- } \\
\text { Descriptive } \\
\text { design. }\end{array}$ & $\begin{array}{l}130 \text { female nurses } \\
\text { working in acute care } \\
\text { units of three } \\
\text { hospitals. }\end{array}$ & $\begin{array}{l}\text { Frequency \& } \\
\text { Descriptive } \\
\text { Statistics. }\end{array}$ & $\begin{array}{l}\text { Occupational Fatigue } \\
\text { Exhaustion Recovery } \\
\text { (OFER), short } \\
\text { demographic } \\
\text { questionnaire. }\end{array}$ & $\begin{array}{l}\text { Mean age }=36.8,42 \% \text { had } \\
\text { family caregiving. } \\
\text { Responsibilities, mean score } \\
\text { for acute fatigue }=65.6 \\
( \pm 18.6) \text { Mean score for } \\
\text { chronic fatigue }=47.3 \\
( \pm 21.8), \text { Mean score for } \\
\text { inter-shift recovery }=65.6 \\
( \pm 18.6)\end{array}$ \\
\hline $\begin{array}{l}\text { Eldevik et al. } \\
\text { (2013) Norway }\end{array}$ & $\begin{array}{l}\text { To determine whether } \\
\text { less than } 11 \text { hours of } \\
\text { work between shifts } \\
\text { (quick returns) is } \\
\text { related to anxiety, } \\
\text { depression, fatigue } \\
\text { insomnia, sleepiness } \\
\text { and shift work disorder } \\
\text { among nurses. }\end{array}$ & $\begin{array}{l}\text { Study } \\
\text { (questionnaire). }\end{array}$ & $\begin{array}{l}1990 \text { nurses Working } \\
\text { in different hospitals. }\end{array}$ & $\begin{array}{l}2 \times 2 \text { chi-square } \\
\text { logistic } \\
\text { regression and } \\
\text { adjusted } \\
\text { analysis. }\end{array}$ & $\begin{array}{l}\text { Bergen Insomnia } \\
\text { Scale, Epworth } \\
\text { Sleepiness Scale } \\
\text { Fatigue } \\
\text { Questionnaire, } \\
\text { Hospital Anxiety \& } \\
\text { Depression Scale, } \\
\text { Shift Work Disorder }\end{array}$ & $\begin{array}{l}\text { Mean=33.2 quick returns } \\
\text { within the last year. } \\
\text { Increased number of quick } \\
\text { returns correlated with an } \\
\text { increase in Bergen Insomnia } \\
\text { Scale, Epworth Sleepiness } \\
\text { Scale, and FQ. Excessive } \\
\text { fatigue was significantly } \\
\text { linked to more than } 30 \text { quick }\end{array}$ \\
\hline
\end{tabular}


Nurse Media Journal of Nursing, 8(2), 2018,127

\begin{tabular}{|c|c|c|c|c|c|c|}
\hline $\begin{array}{l}\text { Authors, Year, \& } \\
\text { Country }\end{array}$ & $\begin{array}{l}\text { Study } \\
\text { Aim }\end{array}$ & $\begin{array}{l}\text { Research } \\
\text { Design }\end{array}$ & $\begin{array}{l}\text { Sample Size and } \\
\text { Characteristics }\end{array}$ & $\begin{array}{l}\text { Method of } \\
\text { analysis }\end{array}$ & Tools used & $\begin{array}{l}\text { Results Related to Nurse } \\
\text { Fatigue }\end{array}$ \\
\hline $\begin{array}{l}\text { Fang et al. (2008) } \\
\text { China }\end{array}$ & $\begin{array}{l}\text { To determine the most } \\
\text { important contributors } \\
\text { to } \\
\text { acute and chronic } \\
\text { fatigue. }\end{array}$ & $\begin{array}{l}\text { Cross-sectional } \\
\text { Descriptive, } \\
\text { correlational } \\
\text { design. }\end{array}$ & $\begin{array}{l}581 \text { Female Nurses } \\
\text { working in different } \\
\text { hospitals. }\end{array}$ & $\begin{array}{l}F \text { statistics and } \\
\text { multiple } \\
\text { regression. }\end{array}$ & $\begin{array}{l}\text { OFER-JCQ- Exposure } \\
\text { of Hazards in Hospital } \\
\text { Work Environments } \\
\text { modified version, } \\
\text { Pittsburg Sleep } \\
\text { Quality Index, -JOB } \\
\text { Dissatisfaction } \\
\text { Scale-Beck Anxiety } \\
\text { Inventory } \\
\text { - Beck Depression } \\
\text { Inventory }\end{array}$ & $\begin{array}{l}\text { returns. A high number of } \\
\text { night shifts and gender were } \\
\text { linked to Shift Work } \\
\text { Disorder (men affected to a } \\
\text { greater extent than women). } \\
\text { Correlation between quick } \\
\text { returns numbers \& night } \\
\text { shifts numbers in the last } \\
\text { year was weak } \& \text { negative (r } \\
=-0.10, \mathrm{p}<0.05) \text {. } \\
\text { Nurses }(30-40 \text { years old) } \\
\text { experienced more acute } \\
\text { fatigue than other nurses } \\
\text { based on age. Experience } \\
\text { differences of acute }(\mathrm{F}=2.85 \text {, } \\
p=0.01) \& \text { chronic ( } \mathrm{F}=5.26, \\
p=0.00) . \text { Hazards exposure } \\
\text { contributed to acute fatigue } \\
(\mathrm{B}=0.15, \mathrm{SE} \mathrm{B}=0.06, \beta=0.08 \text {, } \\
\mathrm{p}<0.05), \text { yet the exposure } \\
\text { failed to contribute to } \\
\text { chronic fatigue. Inter-shift } \\
\text { recovery was the most } \\
\text { important independent } \\
\text { variable that influenced acute } \\
\text { fatigue }(\beta=-0.42) \text {. Exposure } \\
\text { to hazard contributed to } \\
\text { acute fatigue }(\mathrm{B}=0.15, \mathrm{SE} \text {. } \\
\mathrm{B}=0.06, \beta=0.08, \mathrm{p}<0.05), \\
\text { yet the exposure failed to } \\
\text { contribute to chronic fatigue } \\
(\mathrm{B}=0.01, \mathrm{SE} \mathrm{B}=0.06, \\
\beta=0.00) \text {. }\end{array}$ \\
\hline
\end{tabular}




\begin{tabular}{|c|c|c|c|c|c|c|}
\hline $\begin{array}{l}\text { Authors, Year, \& } \\
\text { Country }\end{array}$ & $\begin{array}{l}\text { Study } \\
\text { Aim }\end{array}$ & $\begin{array}{l}\text { Research } \\
\text { Design }\end{array}$ & $\begin{array}{l}\text { Sample Size and } \\
\text { Characteristics }\end{array}$ & $\begin{array}{l}\text { Method of } \\
\text { analysis }\end{array}$ & Tools used & $\begin{array}{l}\text { Results Related to Nurse } \\
\text { Fatigue }\end{array}$ \\
\hline $\begin{array}{l}\text { Han et al. (2014) } \\
\text { United States }\end{array}$ & $\begin{array}{l}\text { To examine the link } \\
\text { among work and non- } \\
\text { work factors, inter-shift } \\
\text { recovery and self- } \\
\text { reported acute and } \\
\text { chronic fatigue. }\end{array}$ & $\begin{array}{l}\text { Cross-sectional } \\
\text { study }\end{array}$ & $\begin{array}{l}80 \text { female nurses } \\
\text { working (12-hour } \\
\text { shifts, not less than } 36 \\
\text { hours per week) in a } \\
\text { large teaching hospital }\end{array}$ & $\begin{array}{l}\text { Pearson chi- } \\
\text { square tests and } \\
\text { Fisher exact } \\
\text { test } \\
\text { for cell } \\
\text { sizes less than } \\
5\end{array}$ & $\begin{array}{l}\text { OFER } \\
\text { Physical demands } \\
\text { adapted Job Content } \\
\text { Questionnaire - } \\
\text { Questionnaire plus } \\
\text { additional nurse- } \\
\text { related items Job } \\
\text { Content Questionnaire }\end{array}$ & $\begin{array}{l}\text { Increased acute fatigue } \\
\text { linked to high psychological } \\
\text { demands }(\mathrm{t}=2.92, \mathrm{p}<0.01) \text {, } \\
\text { greater quantitative work } \\
\text { demands due to workload }(\mathrm{t} \\
=2.51, \mathrm{p}=0.01) \text {, reduced } \\
\text { feedback from co-workers } \\
\text { and supervisors }(\mathrm{t}=-2.95, \mathrm{p} \\
<.01) \& \text { reduced social } \\
\text { support }(\mathrm{t}=-2.75, \mathrm{p}<0.01) \text {. } \\
\text { Working rotating shifts } \\
\text { higher acute fatigue than } \\
\text { fixed shifts }\left(\mathrm{X}^{2}=4.68, \mathrm{p}=\right. \\
0.04) . \mathrm{Chronic} \text { fatigue linked } \\
\text { to low job meaningfulness }(\mathrm{t} \\
=-2.71, \mathrm{p}=0.01), \text { low social } \\
\text { support }(\mathrm{t}=-2.48, \mathrm{p}=0.01) \\
\& \text { low job satisfaction }(\mathrm{t}=- \\
3.74, \mathrm{p}<0.01) .\end{array}$ \\
\hline $\begin{array}{l}\text { Jung \& Lee (2015) } \\
\text { South Korea }\end{array}$ & $\begin{array}{l}\text { To investigate } \\
\text { factors associated with } \\
\text { shift work tolerance } \\
\text { among nurses }\end{array}$ & $\begin{array}{l}\text { Exploratory, } \\
\text { descriptive, } \\
\text { cross-sectional, } \\
\text { correlational } \\
\text { study }\end{array}$ & $\begin{array}{l}660 \text { nurses doing shift } \\
\text { work in a large } \\
\text { hospital }\end{array}$ & $\begin{array}{l}\text { Descriptive } \\
\text { statistics } \\
\text { and Hierarchal } \\
\text { multiple } \\
\text { regression }\end{array}$ & $\begin{array}{l}\text { Diurnal Scale, } \\
\text { Rosenberg Self- } \\
\text { Esteem Scale, } \\
\text { Multidimensional } \\
\text { Scale of Perceived } \\
\text { Social Support, } \\
\text { Korean Occupational } \\
\text { Stress Scale, Insomnia } \\
\text { Severity Index, } \\
\text { Patient Health } \\
\text { Questionnaire - } 9\end{array}$ & $\begin{array}{l}\text { Fatigue score } \mathrm{M}=4.3 \\
(\mathrm{SD}=0.7) \text {, Individual, } \\
\text { lifestyle and working factors } \\
\text { account for an additional } 6 \% \text {, } \\
5 \% \text { \& } 0.2 \% \text { of variance } \\
\text { related to fatigue. Job-stress, } \\
\text { self-esteem \& social support } \\
\text { had a significant positive } \\
\text { correlation to fatigue. }\end{array}$ \\
\hline
\end{tabular}




\begin{tabular}{|c|c|c|c|c|c|c|}
\hline $\begin{array}{l}\text { Authors, Year, \& } \\
\text { Country }\end{array}$ & $\begin{array}{l}\text { Study } \\
\text { Aim }\end{array}$ & $\begin{array}{l}\text { Research } \\
\text { Design }\end{array}$ & $\begin{array}{l}\text { Sample Size and } \\
\text { Characteristics }\end{array}$ & $\begin{array}{l}\text { Method of } \\
\text { analysis }\end{array}$ & Tools used & $\begin{array}{l}\text { Results Related to Nurse } \\
\text { Fatigue }\end{array}$ \\
\hline $\begin{array}{l}\text { Kunert et al. } \\
\text { (2007) United } \\
\text { States }\end{array}$ & $\begin{array}{l}\text { To examine perceptions } \\
\text { differences in for day- } \\
\text { night-shift nurses. }\end{array}$ & $\begin{array}{l}\text { Descriptive } \\
\text { study design. }\end{array}$ & $\begin{array}{l}100 \text { day-shift nurses } \\
\text { and } 90 \text { night-shift } \\
\text { nurses in hospital. }\end{array}$ & $\begin{array}{l}\text { Descriptive and } \\
\text { inferential } \\
\text { statistics. }\end{array}$ & $\begin{array}{l}\text { Brief Fatigue } \\
\text { Inventory Pittsburg } \\
\text { Sleep Quality Index }\end{array}$ & $\begin{array}{l}84 \% \text { females \& } 16 \% \text { males } \\
\text { on night-shift (mean age } \\
32.6) \text {. Night-shift had a } \\
\text { higher Brief Fatigue } \\
\text { Inventory mean total } \\
\text { compared to day-shift ( } \mathrm{p}= \\
0.0001) . \text { Night-shift nurses } \\
\text { had higher Pittsburg Sleep } \\
\text { Quality Index mean global } \\
\text { score compared to day-shift } \\
\text { nurses }(\mathrm{p}=0.0001) \text {. }\end{array}$ \\
\hline $\begin{array}{l}\text { Morelock (2016) } \\
\text { United States }\end{array}$ & $\begin{array}{l}\text { To quantify the } \\
\text { relationships between } \\
\text { factors related to quality } \\
\& \text { safety by examining } \\
\text { the difference in fatigue } \\
\text { perceived overload and } \\
\text { sleep quality among } \\
\text { day-night-shift nurses. }\end{array}$ & $\begin{array}{l}\text { Exploratory } \\
\text { study based on } \\
\text { Sustained } \\
\text { vigilance } \\
\text { model }\end{array}$ & $\begin{array}{l}45 \text { nurses working in } \\
\text { acute care units in a } \\
\text { hospital. }\end{array}$ & $\begin{array}{l}\text { Spearman's rho } \\
\text { test }\end{array}$ & $\begin{array}{l}\text { Brief Fatigue } \\
\text { Inventory, Pittsburg } \\
\text { Sleep Quality Index, } \\
\text { Work overload scale, } \\
\text { Perceived stress scale. } \\
\text { Benner's Stages scale. } \\
\text { Nursing work index- } \\
\text { revised subscale } \\
\text { Researcher-generated } \\
\text { scale. }\end{array}$ & $\begin{array}{l}\text { Fatigue was correlated with } \\
\text { errors (correlation score }= \\
0.48 \mathrm{p}=0.001) \text {, stress level } \\
\text { and errors (correlation } \\
\text { score }=0.41, \mathrm{p}=0.005 \text { ) and } \\
\text { Benner skill level and errors } \\
\text { (correlation score }=0.31, \mathrm{p}= \\
0.037) \text {. A directly } \\
\text { proportional relationship } \\
\text { exists between fatigue and } \\
\text { errors. A significant } \\
\text { difference was found } \\
\text { between day-shift and night- } \\
\text { shift. }\end{array}$ \\
\hline
\end{tabular}




\begin{tabular}{|c|c|c|c|c|c|c|}
\hline $\begin{array}{l}\text { Authors, Year, \& } \\
\text { Country }\end{array}$ & $\begin{array}{l}\text { Study } \\
\text { Aim }\end{array}$ & $\begin{array}{l}\text { Research } \\
\text { Design }\end{array}$ & $\begin{array}{l}\text { Sample Size and } \\
\text { Characteristics }\end{array}$ & $\begin{array}{l}\text { Method of } \\
\text { analysis }\end{array}$ & Tools used & $\begin{array}{l}\text { Results Related to Nurse } \\
\text { Fatigue }\end{array}$ \\
\hline $\begin{array}{l}\text { Nagai et al. (2011) } \\
\text { Japan }\end{array}$ & $\begin{array}{l}\text { Investigate the impact } \\
\text { of fatigue related to } \\
\text { shift } \\
\text { work on immune } \\
\text { function. }\end{array}$ & $\begin{array}{l}\text { Longitudinal } \\
\text { study design }\end{array}$ & $\begin{array}{l}57 \text { female Nurses } \\
\text { working in a public } \\
\text { hospital }\end{array}$ & $\begin{array}{l}\text { Wilcoxon } \\
\text { signed- } \\
\text { rank sum tests }\end{array}$ & $\begin{array}{l}\text { The questionnaire } \\
\text { comprised of } 25 \text { items } \\
\text { that subjectively } \\
\text { assess fatigue } \\
\text { Symptoms. }\end{array}$ & $\begin{array}{l}\text { All fatigue scores } \\
\text { progressively increased from } \\
\text { the beginning of day shifts to } \\
\text { the end of night shifts. Older } \\
\text { and married nurses who had } \\
\text { fewer hours of sleep } \\
\text { demonstrate higher levels of } \\
\text { fatigue. }\end{array}$ \\
\hline $\begin{array}{l}\text { Rahman et al. } \\
\text { (2016) Brunei } \\
\text { Darussalam }\end{array}$ & $\begin{array}{l}\text { To explore and identify } \\
\text { the correlation } \\
\text { between } \\
\text { psychosocial factors } \\
\text { and work-related } \\
\text { fatigue among critical } \\
\text { care and emergency } \\
\text { nurses. }\end{array}$ & $\begin{array}{l}\text { Cross-sectional } \\
\text { Study }\end{array}$ & $\begin{array}{l}201 \text { nurses } \\
\text { Working in different } \\
\text { public hospitals. }\end{array}$ & $\begin{array}{l}\text { Multiple linear } \\
\text { regression } \\
\text { analysis }\end{array}$ & $\begin{array}{l}\text { Copenhagen } \\
\text { Psychosocial } \\
\text { Questionnaire } \\
\text { Version } 2 \\
\text { (COPSQ II) }\end{array}$ & $\begin{array}{l}\text { Nurses employed for a } \\
\text { shorter period of time } \\
\text { experienced higher levels of } \\
\text { acute fatigue }(\mathrm{b}=-0.35,95 \% \\
\mathrm{CL}:-0.67,-0.02) \text {. Stress was } \\
\text { most significantly associated } \\
\text { with chronic fatigue }(\mathrm{r}= \\
0.45, \mathrm{p}<0.001) \text { followed by } \\
\text { work/family conflict and } \\
\text { chronic fatigue }(\mathrm{r}=0.44, \mathrm{p}< \\
0.001) \text { and lastly stress was } \\
\text { associated with inter-shift } \\
\text { recovery ( } \mathrm{r}=-0.41, \mathrm{p}< \\
0.001) .\end{array}$ \\
\hline $\begin{array}{l}\text { Winwood et al. } \\
\text { (2006) Australia }\end{array}$ & $\begin{array}{l}\text { To determine the } \\
\text { relationship } \\
\text { among a number of } \\
\text { varying factors such as } \\
\text { age, domestic } \\
\text { responsibilities } \\
\text { (dependents and } \\
\text { significant others), } \\
\text { recovery from fatigue- } \\
\text { related to shift work }\end{array}$ & Questionnaire & $\begin{array}{l}1280 \text { female } \\
\text { nurses working in two } \\
\text { hospitals }\end{array}$ & $\begin{array}{l}\text { Pearson's r } \\
\text { bivariate } \\
\text { correlations, } \\
\text { ANOVA and } \\
\text { MANOVA }\end{array}$ & $\begin{array}{l}\text { OFER and } \\
\text { Three } \\
\text { subscales: OFFER- } \\
\text { AF, OFER-CF, and } \\
\text { OFER-IR }\end{array}$ & $\begin{array}{l}\text { Age and OFER-IR positively } \\
\text { correlated, which is } \\
\text { suggestive of better recovery } \\
\text { among older nurses. } \\
\text { Increased age is correlated } \\
\text { with significantly lower } \\
\text { levels of acute fatigue }[\mathrm{F} \\
(4,832)=3.75(\mathrm{p}=0.005)] \\
\text { and chronic fatigue }[\mathrm{F} \\
(4,832)=3.79(\mathrm{p}=0.005)]\end{array}$ \\
\hline
\end{tabular}




\begin{tabular}{|c|c|c|c|c|c|}
\hline $\begin{array}{l}\text { Authors, Year, \& } \\
\text { Country }\end{array}$ & $\begin{array}{l}\text { Study } \\
\text { Aim }\end{array}$ & $\begin{array}{l}\text { Research } \\
\text { Design }\end{array}$ & $\begin{array}{l}\text { Sample Size and } \\
\text { Characteristics }\end{array}$ & $\begin{array}{l}\text { Method of } \\
\text { analysis }\end{array}$ & $\begin{array}{l}\text { Results Related to Nurse } \\
\text { Fatigue }\end{array}$ \\
\hline & $\begin{array}{l}\text { and maladaptive health } \\
\text { outcome among full- } \\
\text { time female nses. }\end{array}$ & & & & 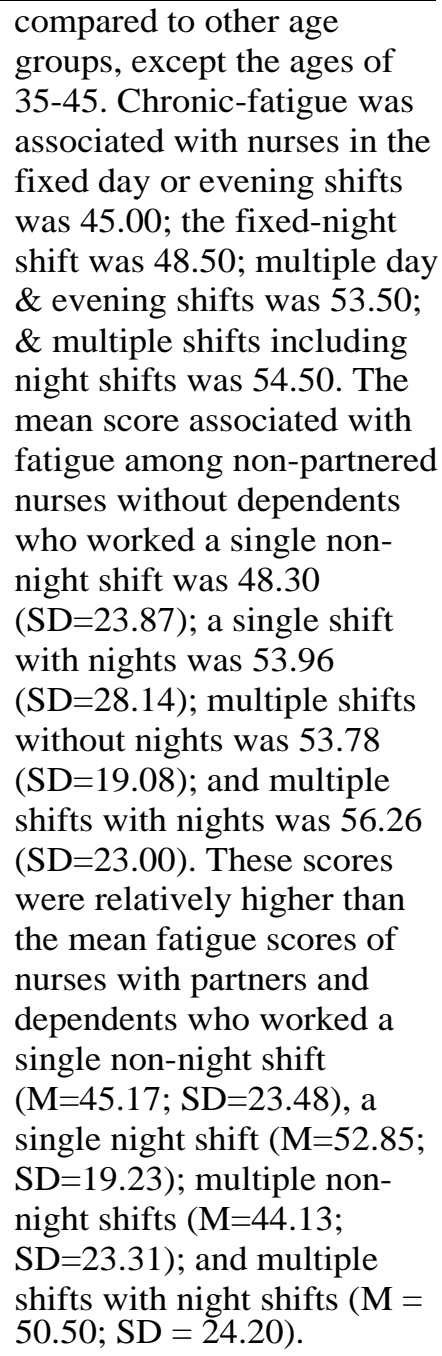 \\
\hline
\end{tabular}


Nurse Media Journal of Nursing, 8(2), 2018, 132

\begin{tabular}{|c|c|c|c|c|c|c|c|}
\hline $\begin{array}{l}\text { Authors, Year, \& } \\
\text { Country }\end{array}$ & $\begin{array}{l}\text { Study } \\
\text { Aim }\end{array}$ & & $\begin{array}{l}\text { Research } \\
\text { Design }\end{array}$ & $\begin{array}{l}\text { Sample Size and } \\
\text { Characteristics }\end{array}$ & $\begin{array}{l}\text { Method of } \\
\text { analysis }\end{array}$ & Tools used & $\begin{array}{l}\text { Results Related to Nurse } \\
\text { Fatigue }\end{array}$ \\
\hline \multicolumn{2}{|c|}{ Authors, Year, \& Country } & Phenomena o & Interest & Methodology & Participants & Reported Themes & \\
\hline \multicolumn{2}{|c|}{$\begin{array}{l}\text { Steege \& Rainbow (2017) } \\
\text { United States }\end{array}$} & \multicolumn{2}{|c|}{ Nurses' experience } & $\begin{array}{l}\text { Qualitative } \\
\text { exploratory }\end{array}$ & 22 & $\begin{array}{l}\text { New construct: } \\
\text { 'Supernurse' } \\
\text { Subtheme: } \\
\text { Alter ego, Cloak of } \\
\text { invulnerability, } \\
\text { Extraordinary powers } \\
\text { used for the greater } \\
\text { good, Kryptonite, No } \\
\text { sidekick }\end{array}$ & \\
\hline
\end{tabular}


Table 4. Factors influencing fatigue among hospital nurses

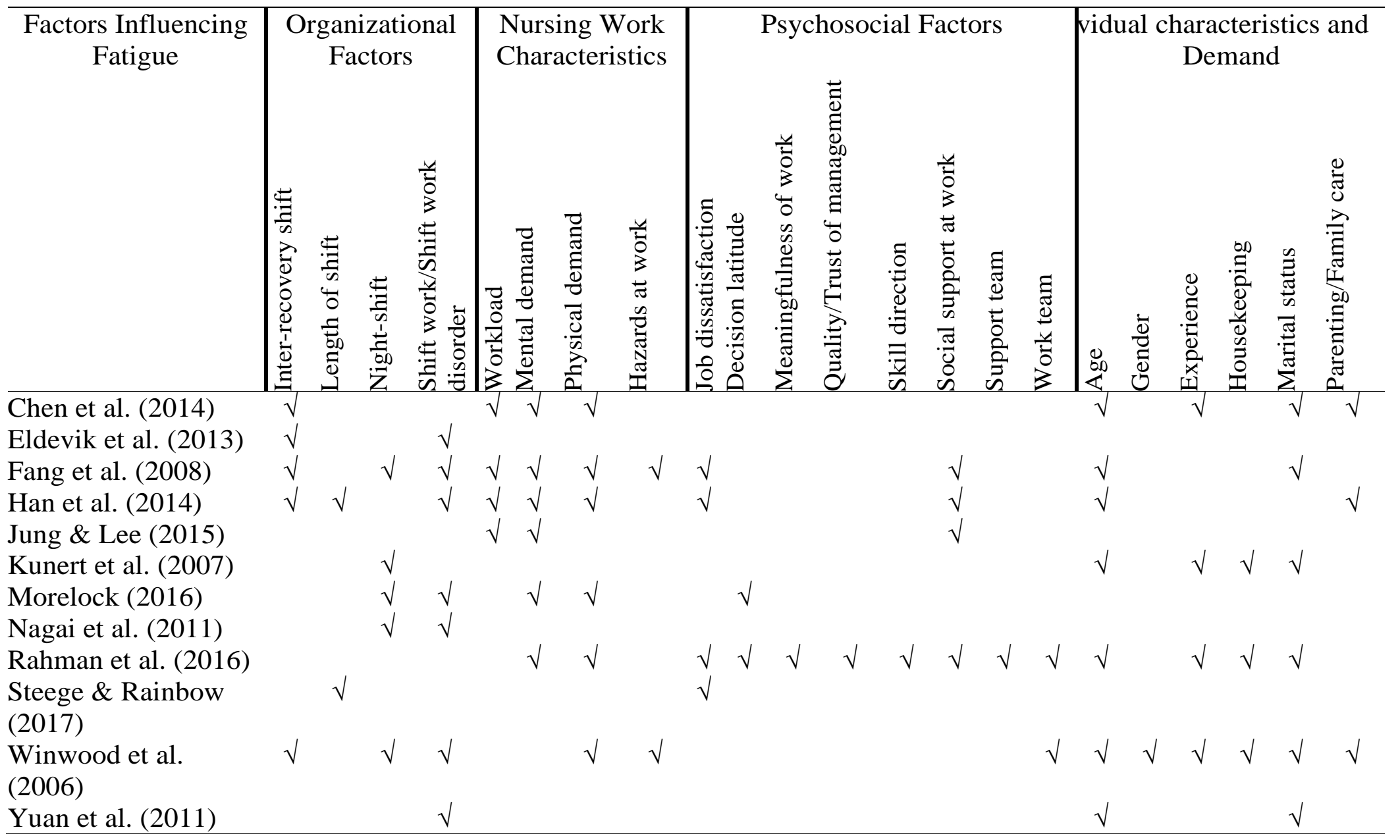

